\title{
Konsep desain lanskap Stasiun Kedungjati Kabupaten Grobogan Jawa Tengah
}

\author{
Novia Andriyani ${ }^{1}$, Naniek Kohdrata ${ }^{1 *}$, Ni Luh Made Pradnyawathi² \\ 1. Prodi Arsitektur Pertamanan, Fakultas Pertanian, Universitas Udayana, Jl. PB Sudirman Denpasar, \\ Indonesia \\ 2. Prodi Agroekoteknologi, Fakultas Pertanian, Universitas Udayana, JL PB Sudirman Denpasar, \\ Indonesia \\ *E-mail : naniek_kohdrata@unud.ac.id
}

\begin{abstract}
Landscape Design Concept of Kedungjati Train Station in Grobogan Regency Central Java. Kedungjati train station is one of the oldest stations in Indonesia which was built by NISM (Nederlandsh Indische Spoorweg Maatschappij). It was inaugurated in 21 May 1873. Kedungjati Station is currently expanding its functions. There are some activities that do not support or threatening future concervation goals of the train station, since there a no landscape design concept yet. Therefore, it is necessary to have a conceptual design planning as a start of supporting the Kedungjati train station site conservation an development. This study aims to determine the additional of functions at the Kedungjati Station and share zones of the Kedungjati Station so that it can support preservation of station historic buildings by accommodating current functions. The concept of landscape design at Kedungjati Station is done by collecting biophysical, social, historical and managerial policies on the site, then analyzing and synthesizing. Some old features of the train facilities shall be conserved and utilize as object of interest at the station. The concept of landscape design that supports the preservation of buildings as cultural heritage buildings is the Indis landscape design concept.
\end{abstract}

Keywords: Concept, Design, Kedungjati, Landscape, Station.

\section{Pendahuluan}

Cagar budaya merupakan sebuah peninggalan sejarah yang dapat berupa benda, struktur, situs, bangunan atau kawasan yang berusia lebih dari 50 tahun, memiliki arti khusus bagi sejarah, ilmu pengetahuan, pendidikan, agama dan kebudayaan serta memiliki nilai budaya bagi penguatan kepribadian bangsa (UndangUndang No. 11 Tahun 2010 tentang Cagar Budaya). Salah satu dari peninggalan sejarah di Indonesia adalah Stasiun Kedungjati yang terdaftar sebagai cagar budaya milik PT. KAI dengan Nomor Induk Objek Benda OBPO2015050800052 (http://cagarbudaya.kemendikbud.go.id).

Stasiun Kedungjati merupakan salah satu stasiun tertua di Indonesia yang sudah terdaftar sebagai cagar budaya dan terletak di Kabupaten Grobogan Jawa Tengah. Pada zaman kolonial, Belanda memutuskan untuk membangun stasiun kereta api di Desa Kedungjati Kecamatan Kedungjati yang menghubungkan antara Semarang dengan Surakarta melalui jalur kereta api untuk mempermudah mengangkut dan membawa hasil hutan dari daerah Kedungjati yang tidak lain adalah kayu jati (Apiwie dan Utomo, 2015). Belum terdapat penataan lanskap di stasiun ini, hal ini dapat dilihat dari masyarakat yang bisa leluasa masuk ke dalam tapak dari segala arah, serta lahan kosong pada tapak yang masih terbengkalai dan dimanfaatkan secara liar oleh masyarakat. Terdapat tumpukan besi dan kayu bekas rel kereta yang dibiarkan begitu saja di halaman stasiun. Belum terdapat penataan lanskap pada Stasiun Kedungjati dikhawatirkan dapat menyebabkan penurunan kualitas pada lanskap stasiun, maka dari itu konsep desain lanskap diperlukan untuk mendukung kelestarian Stasiun Kedungjati.

\section{Metode Penelitian}

Penelitian dilaksanakan di Stasiun Kedungjati, Kabupaten Grobogan, Jawa Tengah. Penelitian dilakukan selama enam bulan dari bulan Maret 2018 sampai dengan Agustus 2018. Penelitian dilaksanakan di Stasiun Kereta Api Kedungjati dengan batasan penelitian membuat konsep desain lanskap Stasiun Kedungjati. Metode penelitian yang digunakan adalah metode survei.Tahapan penelitian ini mengadaptasi pada tahapan penelitian menurut Gold (1980) yaitu inventaris, analisis, penetapan konsep dan desain. 


\section{Hasil dan Pembahasan}

\subsection{Gambaran Umum lokasi penelitian}

Stasiun Kedungjati dengan kode KEJ merupakan stasiun kereta api yang terletak di Kecamatan Kedungjati, Kabupaten Grobogan Jawa Tengah. Stasiun ini dibangun pada Tahun 1868 oleh perusahaan perkeretaapian Hindia Belanda yaitu NISM (Nederlandsch-Indische Spoorweg Maatschappij) dan diresmikan pada Tanggal 21 Mei 1873. Stasiun kereta api Kedungjati memiliki enam jalur rel dan 24 wesel di setiap persimpangan jalur. Stasiun Kedungjati melayani perjalanan umum untuk masyarakat dengan rute KedungjatiSemarang, Kedungjati-Pasar Senen, Kedungajati-Solo, dan Kedungjati-Malang. Stasiun ini berbatasan langsung dengan permukiman warga, hanya terdapat satu jalan masuk menuju Stasiun Kedungjati. Pada tapak tidak hanya terdapat bagunan utama stasiun, terdapat bangunan lain seperti rumah dinas yang diperuntukkan pegawai stasiun dan disewakan juga untuk umum, selain itu terdapat bangunan gudang, UPT Resort Jalur ler, menara, ruang genset dan toilet pengunjung yang bangunannya terpisah dari bangunan utama stasiun.

\subsection{Inventarisasi Aspek Biofisik}

Stasiun Kedungjati terletak di Jalan Raya Gubug-Kedungjati tepatnya berada di Kecamatan Kedungjati, Kabupaten Grobogan, Jawa Tengah. Stasiun Kedungjati memiliki lebar bangunan 25 m, pangjang $93 \mathrm{~m}$, dan tinggi $12 \mathrm{~m}$ (BPCB Jateng, 2013). Berdasarkan penelitian yang dilakukan batas tapak Stasiun Kedungjati pada bagian depan atau sebelah barat yaitu berbatasan langsung dengan Jalan Raya GubugKedungjati dan juga pertokoan, di depan stasiun terdapat pangkalan ojek serta terminal bus kecil. Batas pada bagian selatan dibatasi dengan pagar yang dibangun oleh PT. KAI dan berbatasan langsung dengan perkampungan warga serta kantor polisi hutan. Batas sebelah utara berbatasan dengan jalan dan perkampungan warga. Akses untuk menuju Stasiun Kedungjati dapat dijangkau dengan menggunakan kendaraan bermotor roda dua maupun roda empat. Akses lainnya dengan menggunakan kereta api. Tapak dilalui jalan raya yang sudah berasapal, jaringan jalan menuju Stasiun Kedungjati dapat ditempuh melewati jalan lokal yaitu Jalan Raya Gubug - Kedungjati, Salatiga-Kedungjati dan Jalan Kedungjati - Karanggede. Fasilitas yang terdapat pada tapak yaitu loket tiket, ruang tunggu, ruang tunggu kelas eksekutif, mushola, toilet, dan tempat parkir.

Berdasarkan data Badan Pusat Statistik (BPS) 2018, Kecamatan Kedungjati yang berada di Kabupaten Grobogan bagian selatan mempunyai jenis tanah regosol. Topografi pada tapak cenderung datar dengan kemiringan $0-8^{\circ}$. Tapak berada pada ketinggian 36 meter di atas permukaan laut. Sumber air pada tapak yaitu sumur artesis dan juga air PDAM yang digunakan untuk kegiatan pada Stasiun Kedungjati. Pada bangunan stasiun terdapat drainase berupa selokan pada pinggir - pinggir bangunan, sedangkan drainase pada luar bangunan terdapat jalur drainase selokan kecil yang lebarnya kurang lebih $30 \mathrm{~cm}$ dan dalam $30 \mathrm{~cm}$ di samping jalan beraspal menuju stasiun.

IKlim di Kecamatan Kedungjati mengacu pada iklim Kabupaten Grobogan Jawa Tengah karena wilayah Kedungjati termasuk dalam wilayah Kabupaten Grobogan. Berdasarkan data dari Badan Pusat Statistik Provinsi Jawa Tengah pada tahun 2010 - 2017 suhu rata-rata di Kabupaten Grobobogan yaitu $28^{\circ} \mathrm{C}$, curah hujan rata-rata $185,4 \mathrm{~mm}$, kelembaban udara rata-rata sebesar $76,6 \%$, lama penyinaran matahari ratarata sebesar $71,2 \%$, dan kecepatan angin rata-rata $6,5 \mathrm{~km} / \mathrm{jam}$. Terdapat cukup banyak jenis tanaman pada tapak. Tanaman yang terdapat pada tapak beragam mulai dari tanaman penutup tanah, semak, perdu, hingga pohon. Tanaman pada tapak contohnya Samanea saman, Mangifera indica, Polyalthia longifolia dan Cocos nucifera. Satwa pada tapak terdapat berbagai jenis serangga seperti kupu-kupu, belalang, jangkrik, capung dan juga burung.

Good view yang terdapat pada Stasiun Kedungjati yaitu bangunan stasiun yang memiliki arsitektur gaya Belanda. Arsitektur bangunan Stasiun Kedungjati dapat dilihat pada Gambar 1. 


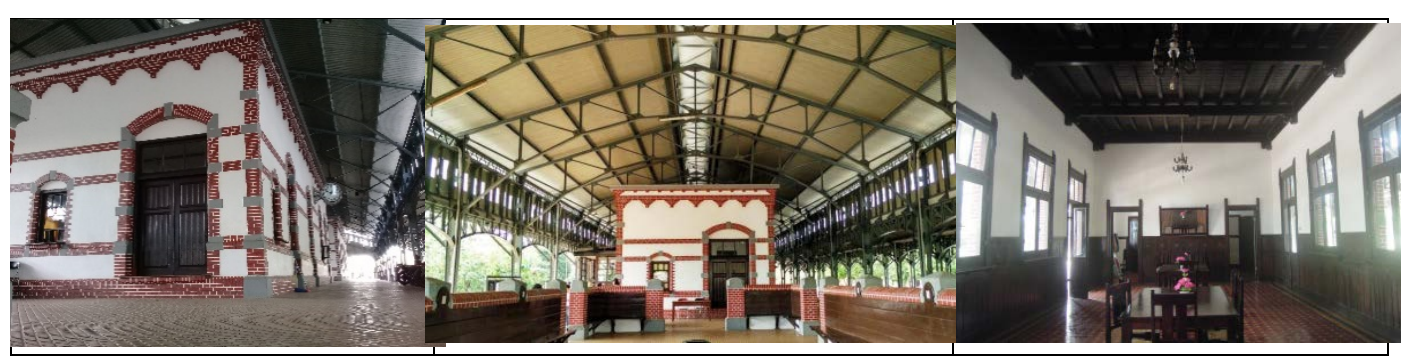

Gambar 1. Arsitektur Stasiun Kedungjati

Good view sekitar stasiun yaitu dilihat dari jalan masuk dan dari arah barat masuk menuju stasiun, begitu juga sebaliknya dari arah stasiun menuju keluar ke jalan raya sebelah barat terdapat pertokoan yang di belakangnya terdapat bukit yang dapat dilihat dari stasiun. Kereta api yang datang dan berhenti di stasiun menjadi daya tarik bagi masyarakat dan pengunjung. Sedangkan bad view pada tapak yaitu terdapat perumahan warga pada area Stasiun Kedungjati. Terdapat tumpukan kayu dan besi bekas rel kereta yang sudah tidak digunakan dan ditumpuk di halaman stasiun. Proses pengerjaan jalur Kedungjati-Ambarawa yang terhenti menjadi pemandangan yang kurang menarik pada tapak. Kebisingan di Stasiun Kedungjati berdasarkan pengukuran yaitu sebesar $53 \mathrm{db}$. Pengukuran dilakukan dengan menggunakan perangkat telepon genggam yang sudah diinstal dengan aplikasi pengukur tingkat kebisingan (Sound Level Meter).

\subsection{Inventarisasi Aspek Sosial}

Kecamatan Kedungjati merupakan kecamatan paling selatan di Kabupaten Grobogan, mempunyai luas 130,344 km² dan secara administratif Kecamatan Kedungjati terdiri dari dua belas desa. Jumlah penduduk di Kecamatan Kedungjati pada tahun 2017 sebesar 345 jiwa / km². Data demografi di Kecamatan Kedungjati menunjukkan masyarakat sekitar tapak rata-rata bermata pencaharian sebagai petani, hal ini dilihat lahan sawah pada tahun $20174,192 \mathrm{~km}^{2}$ dan lahan tegalan mencapai $11,410 \mathrm{~km}^{2}$, Kecamatan Kedungjati sendiri di dominasi oleh hutan jati yang memiliki luas mencapai $100,227 \mathrm{~km}^{2}$ dari seluruh wilayah yang dimiliki. Perekonomian di Kecamatan Kedunjati tidak hanya dari pertanian, banyak terdapat pasar-pasar kecil dan petokoan sebagai lapangan usaha masyarakat (Badan Pusat Statistik, 2018).

Pengguna tapak terdiri dari berbagai usia mulai dari anak kecil, remaja, serta orang dewasa. Aktivitas yang terdapat pada tapak sangat beragam tidak hanya sekedar aktivitas pelayanan perjalanan kereta api. Aktivitas yang biasa dilakukan masyarakat pada tapak yaitu seperti berolahraga, berkumpul bersama, melihatlihat bangunan stasiun, bahkan mengadakan acara hiburan. Intensitas masyarakat mengunjungi stasiun dan beraktivitas cukup sering, yaitu setiap hari dari pagi hingga sore.

Stasiun Kedungjati saat ini dikelola oleh PT.KAI dan termasuk dalam Daerah Operasi IV Semarang dan dikelola bagian Heritage. Stasiun Kedungjati terdaftar sebagai bangunan cagar budaya pada Tahun 2015 dengan Nomor Induk Objek Benda OBPO2015050800052. Stasiun Kedungjati dikelola di bawah naungan Balai Pelestarian Cagar Budaya Jawa Tengah. Struktur organisasi di Stasiun Kedungjati terdiri dari Kepala Stasiun, Wakil Kepala dan beberapa petugas lainnya.

\subsection{Inventarisasi Aspek Sejarah}

Bangunan Stasiun Kedungjati pertama kali dibangun pada Tahun 1868 oleh NISM. Bentuk bangunan mengalami perubahan dari pertama kali dibangun dan setelah dipugar pada Tahun 1907 yang awalnya dari kayu menjadi bata berplester. Pemugaran kembali dilakukan pada Tahun 1991 dengan penambahan atap pada bagian peron di samping kanan dan kiri bangunan utama. Alat perkeretaapian di Stasiun Kedungjati merupakan alat perkeretaapian generasi kedua yang masih digunakan hingga saat ini. Arsitektur bangunan Stasiun Kedungjati masih sangat kental dengan arsitektur bangunan gaya Belanda. Ciri khas bangunan arsitektur kolonial adalah proporsi bangunan yang tidak skala manusia atau tidak sesuai dengan proporsi tubuh manusia memungkinkan menjadi bentuk yang besar dan megah. Bangunan Stasiun Kedungjati memiliki keunikan dari material yang digunakan yaitu dari batu bata dan lantai tegel yang khas dari stasiun NISM.

Estetika tapak terletak pada bangunan stasiun yang memiliki bentuk yang khas dan indah serta berbeda dari bangunan lainnya di sekitar tapak. Stasiun Kedungjati saat ini sudah berusia 151 tahun. Stasiun 
Kedungjati dahulu digunakan untuk mempermudah mengangkut kayu jati dari wilayah Kedungjati sendiri yang memang merupakan kawasan hutan jati hingga saat ini.

\subsection{Analisis dan Sintesis Aspek Biofisik}

Stasiun Kedungjati terletak di pinggir Jalan Raya Salatiga-Kedungjati dan Gubug - Kedungjati sehingga memudahkan akses menuju stasiun tersebut. Letak stasiun yang terletak di pinggir jalan merupakan salah satu potensi untuk pengembangan stasiun. Lokasi stasiun yang berada di Kecamatan Kedungjati, Kecamatan paling selatan di Kabupaten Grobogan dan merupakan perbatasan antara Kabupaten Grobogan dan Kabupaten Boyolali merupakan kendala yang membuat tapak kurang dikenal oleh masyarakat luas. Solusi yang dapat dilakukan untuk mengatasi masalahan tapak yang kurang dikenal oleh masyarakat luas karena terletak di perbatasan dapat dilakukan dengan menambah kereta yang melintas dan berhenti di Stasiun Kedungjati. Media sosial, dapat dimanfaatkan untuk promosi seperti menggunakan kereta api, menjelaskan sejarah yang ada pada tapak dan ajakan untuk mengunjungi tapak, termasuk menampilkan jadwal keberangkatan dan kedatangan kereta api.

Lahan stasiun cukup luas namun beberapa bagian digunakan untuk mendirikan rumah tinggal oleh warga sekitar membuat luas Stasiun Kedungjati saat ini terlihat tidak begitu luas. Batas tapak juga tidak nampak jelas karena terdapat rumah rumah warga disekitar bangunan stasiun, meskipun di sebelah selatan stasiun sudah terdapat pagar pembatas yang dibangun oleh PT.KAI (persero) namun masih terdapat rumahrumah warga di dalam pagar. Hal ini dapat menjadi kendala untuk pengelolaan bangunan stasiun sebagai peninggalan sejarah karena kawasan stasiun yang tidak mempunyai batas yang jelas mengakibatkan semua orang dapat mengakses stasiun dengan bebas dari segala arah. Rumah-rumah warga yang berada persis di samping stasiun dapat direlokasi sedangkan batas yang tidak jelas harus dibuat pagar pembatas mengelilingi lahan stasiun.

Kemudahan akses menuju tapak dengan menggunakan transportasi kereta api dan kendaraan bermotor menjadi keuntungan untuk pengembangan tapak. Jaringan jalan menuju Stasiun Kedungjati terdapat dua jalan utama yaitu Jalan Raya Salatiga-Kedungjati dan Jalan Raya Gubug - Kedungjati, kedua jalan tersebut merupakan jalan utama untuk menuju lokasi tapak sehingga dipastikan akses menuju stasiun sangat mudah. Pola sirkulasi pada tapak yaitu menggunakan pola linear. Kendaraan yang keluar masuk stasiun masih menggunakan satu jalan untuk dua arah yaitu masuk dan keluar. Penggunaan satu jalan untuk dua arah keluar dan masuk dirasa belum memadai, sebaiknya terdapat dua jalan untuk masuk dan keluar tapak. Fasilitas yang terdapat pada stasiun saat ini sudah cukup menunjang dan bahkan menarik masyarakat untuk mengunjungi stasiun, namun perlu penambahan fasilitas seperti akses untuk pejalan kaki dan ram untuk masuk ke dalam stasiun diperuntukan penyandang disabilitas. Fasilitas penunjang lainnya yang perlu ditambahkan yaitu kantin untuk memenuhi kebutuhan pengunjung dan pegawai stasiun. Penambahan ruang laktasi juga sangat diperlukan untuk menunjang kebutuhan pengguna stasiun bagi ibu menyusui dan ruang merokok, dan ramburambu larangan yang diperuntukkan bagi pengunjung untuk tidak merusak bangunan stasiun.

Jenis tanah pada Kabupaten Grobogan kususnya Kecamatan Kedungjati merupakan tanah berjenis regosol. Tanah regosol adalah salah satu jenis tanah marjinal di daerah beriklim tropika basah yang mempunyai produktivitas rendah tetapi masih dapat dikelola dan digunakan untuk usaha pertanian (Hakim dan utomo, 2003). Berdasarkan pengertian tanah regosol tersebut dapat digunakan sebagai media tanam meskipun tidak terlalu subur. Jenis tanaman yang dapat tumbuh pada tanah regosol yaitu tanaman yang tidak terlalu banyak membutuhkan air seperti jenis tanaman palawija dan tanaman hias seperti Araceceae sp. dan Sansevieria sp. Topografi pada tapak cenderung datar menjadi keuntungan karena akan lebih mudah dimanfaatkan. Jalur rel kereta Kedungjati-Ambarawa yang dibangun di bawah dengan kedalaman kurang lebih satu hingga dua meter menjadi keuntungan, jalur tersebut dapat diperdalam dan dibangun jembatan di atasnya untuk mempermudah melewati jalur kereta api.

Sumber air pada tapak sendiri tidak terdapat kendala yang serius karena kebutuhan air pada tapak masih terpenuhi dengan air dari sumur artesis dan air PDAM. Kondisi tapak yang mayoritas masih tanah belum diperkeras dengan aspal maupun benton mempermudah penyerapan air. Drainase pada tapak cukup baik, meskipun saluran drainase pada luar bangunan masih terdapat genangan air ketika turun hujan dan hal tersebut menjadi kendala, sehingga perlu adanya penataan saluran drainase yang lebih baik dalam konsep desain supaya tidak terdapat air menggenang. Saluran drainase sebaiknya dibuat lebih lebar dan lebih dalam 
serta kemiringan yang cukup supaya dapat menampung dan mengalirkan air ketika hujan turun dan tidak terdapat genangan air pada saluran drainase, karena hal tersebut membuat pemandangan yang kurang menarik pada tapak. Air hujan dan air bekas pakai dari kamar mandi sebaiknya dialirkan melalui drainase bawah tanah yang dihubungkan dengan drainase utama pada pinggir jalan raya dan dialirkan menuju sungai.

Kondisi iklim pada lokasi penelitian yaitu suhu rata-rata yaitu $28^{\circ} \mathrm{C}$, curah hujan rata-rata $185,4 \mathrm{~mm}$, kelembaban udara rata-rata sebesar $76,6 \%$, lama penyinaran matahari rata-rata sebesar $71,2 \%$, dan kecepatan angin rata-rata $6,5 \mathrm{~km} / \mathrm{jam}$. Tingkat kenayamanan pada tapak dapat dihitung dengan rumus $\mathrm{THI}$ (Thermal Humidity Index).

$$
\mathrm{THI}=0,8 \mathrm{~T}+(\mathrm{RH} \times \mathrm{T}) / 500
$$

Keterangan :

$\begin{array}{ll}\text { THI } & \text { : Thermal Humidity Index } \\ \mathrm{T} & \text { : Temperatur / Suhu }\end{array}$

$\mathrm{RH} \quad$ : Kelembaban

Hasil perhitungan THI yang digunakan untuk menentukan index kenyamanan, dimana THI = 21-27 nyaman dan THI $>27$ tidak nyaman (Laurine, 1986). Suhu rata-rata $28^{\circ} \mathrm{C}$ dan kelembaban rata-rata $76.6 \%$. Maka didapat THI sebesar 22.44. Nilai THI tersebut berada pada kisaran nyaman. Suhu pada tapak tidak terlalu panas dan tanaman eksisting terdiri dari pohon peneduh membuat tapak terasa sejuk tidak terlalu panas karena paparan sinar matahari tidak mengarah langsung. Kondisi tapak yang tidak terlalu panas menjadi nilai lebih untuk pengembangan tapak. Penambahan tanaman yang berfungsi sebagai peneduh tetap harus dilakukan untuk mengurangi panas matahari yang masuk saat siang hari. Penambahan tanaman dilakukan juga untuk menyerap air ketika hujan turun supaya tidak banyak air menggenang ketika musim hujan.

Penambahan jenis tanaman baru mulai dari ground cover, semak, perdu hingga pohon akan ditambahkan untuk menunjuang kelestarian dan daya tarik tapak. Keberadaan satwa seperti burung dan serangga sepatutnya dipertahankan karena akan menciptakan lingkungan yang asri dan alami. Jenis burung yang dapat dijumpai pada tapak yaitu burung gereja (Passer montanus) sedangkan jenis serangga yang dapat dijumpai pada tapak seperti capung, belalang, kupu-kupu dan jangkrik. Keberadaan satwa tersebut menjadi keuntungan bagi tapak karena akan memberikan dampak positif bagi tapak yang akan terlihat asri. Jenis satwa yang harus dipertahankan dan ditambah jumlahnya adalah burung.

Good view pemandangan dari stasiun ke arah barat akan terlihat perbukitan di balik pertokoan yang menjadi daya tarik tersendiri untuk mengunjungi stasiun, kemudian jajaran pohon trembesi (Samanea saman) yang berjajar rapi dan tampak seimbang di halaman Stasiun Kedungjati yang biasanya menjadi spot selfie untuk pengunjung terutama usia remaja. Good view yang terdapat pada tapak dapat lebih dikembangkan dengan menataan ruang terbuka stasiun. Penambahan taman dan ruang terbuka hijau untuk memperindah tapak. Tumpukan kayu dan besi yang menjadi bad view karena sudah tidak terpakai lebih baik disingkirkan atau dipindahkan dari halaman stasiun karena membuat stasiun terkesan kotor. Halaman stasiun yang tadinya digunakan untuk menumpuk kayu dan besi yang sudah tidak terpakai dapat dimanfaatkan untuk ruang terbuka atau taman guna memperindah tapak. Rumah-rumah liar warga yang dibangun di dalam tapak sebaiknya direlokasi untuk kelestarian tapak kedepannya. Perlu adanya pengembangan dari segi visual dalam tapak untuk menarik minat pengunjung. Penambahan taman pada median jalan memasuki stasiun sebagai daya tarik serta penataan lanskap pada lahan kosong di dalam tapak diharapkan supaya pengunjung tidak berpusat pada bangunan stasiun dan halaman stasiun saja. Analisis good view dan bad view dapat dilihat pada Gambar 2. 


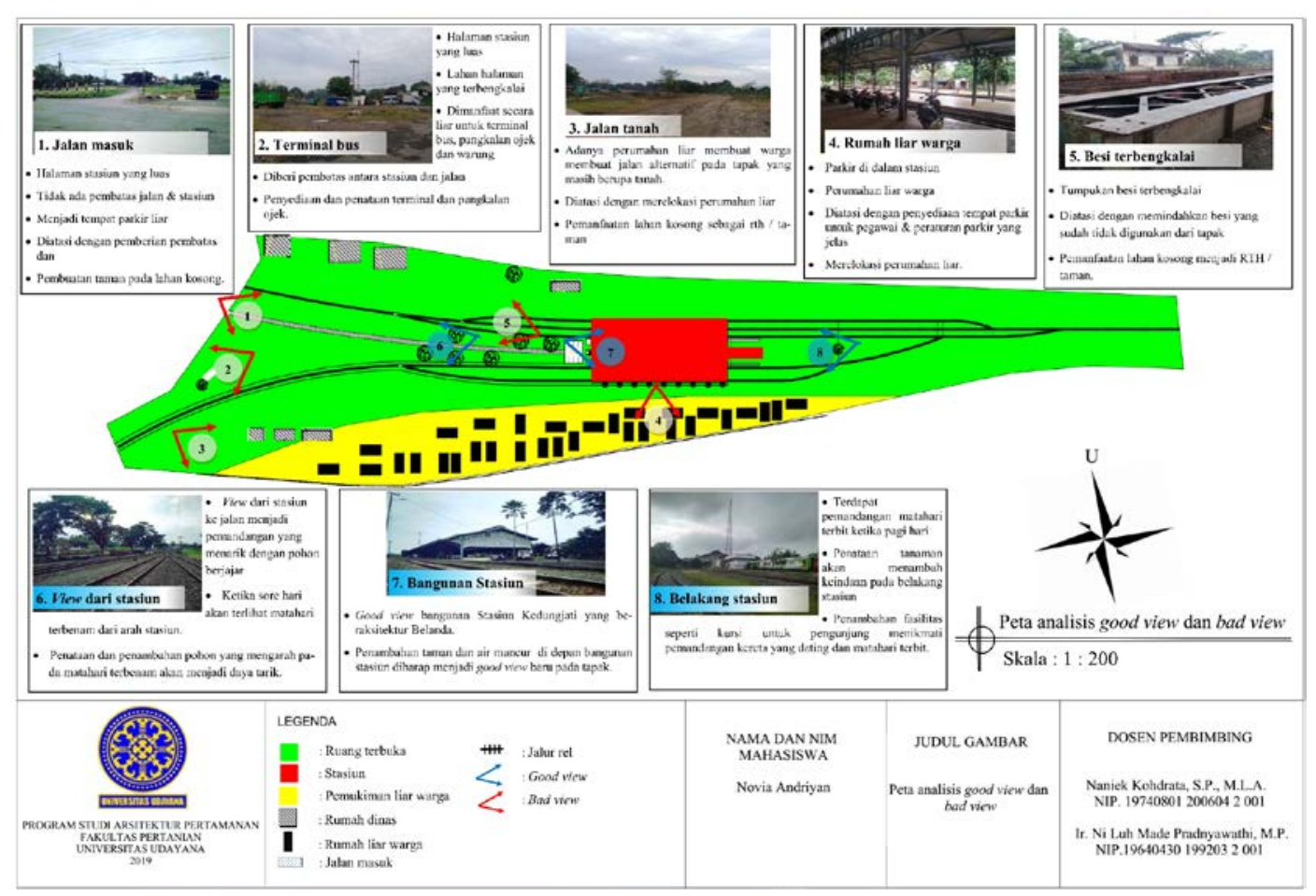

Gambar 2. Peta Analisis good view dan bad view

Tingkat kebisingan pada tapak yang merupakan stasiun kereta api yaitu 53db relatif tidak terlalu bising dan masih tergolong aman. Tapak tidak terlalu bising karena tidak banyak kereta yang melewati stasiun ini, jarak stasiun dan jalan raya yang cukup jauh dan juga lokasi stasiun yang berada pada kecamatan kecil dan perbatasan serta belum padat. Untuk mengantisipasi peningkatan kebisingan pada tapak apabila seluruh jalur rel berfungsi setiap saat dan banyak kereta api yang melintas dan berhenti, serta kebisingan dari luar tapak dilakukan dengan penanaman vegetasi multi strata dan pemilihan jenis tanaman hias yang memiliki daun kecil dan kerapatan tinggi untuk mereduksi kebisingan contohnya Syzygium campanutalum dan Ixora javanica.

\subsection{Analisis dan Sintesis Aspek Sosial}

Kecamatan Kedungjati memiliki luas wilayah 130.344 km² dan jumlah penduduk 345 jiwa / km², jumlah tersebut masih tergolong sedikit dengan luas wilayah yang cukup luas meskipun didominasi oleh hutan jati. Penduduk yang bermata pencaharian sebagai petani dan pedagang menjadi keuntungan bagi tapak karena para petani akan menggunakan transportasi kereta api menuju kota untuk membeli benih, bibit, pupuk dan peralatan bertani serta menjual hasil pertanian ke kota menggunakan kereta api. Penduduk yang bermata pencaharian sebagai pedagang juga memberi keuntungan karena banyak pedagang menggunakan transportasi kereta api untuk aktivitas perdagangan keluar kota.

Pengguna tapak yang terdiri dari berbagai usia harus diimbangi dengan desain yang ramah terhadap anak kecil dan juga lanjut usia pada tapak, supaya kunjungan pada tapak tetap aman dan nyaman. Masyarakat yang sering menggunakan kereta api melalui Stasiun Kedungjati akan menjadi potensi dan keuntungan.

\subsection{Analisis dan Sintesi Aspek Sejarah}

Banguanan Stasiun Kedungjati awal mula dibangun dengan konstruksi kayu kemudian dilakukan renovasi pada Tahun 1907 dan Tahun 1991 yang merubah konstruksi bangunan dari kayu menjadi bata beratap baja yang bertahan hingga saat ini. Peralatan yang terdapat pada stasiun yang masih asli seperti jam, kaca, kursi dan lonceng. Benda-benda yang merupakan peninggalan asli dari jaman kolonial Belanda tersebut mempunyai nilai sejarah tersendiri dan masih dapat digunakan hingga saat ini sehingga akan menjadi daya tarik bagi pengunjung. Rata-rata pengunjung yang datang tidak mengetahui persis apakah benda tersebut asli sejak pertama stasiun dibangun atau benda baru, sehingga perlu adanya tanda yang menunjukkan sejarah benda tersebut sebagai edukasi bagi pengunjung. 
Stasiun yang berusia 151 tahun menjadi potensi sebagai daya tarik bagi pengunjung untuk melihat bangunan bersejarah. Aktivitas stasiun Kedungjati pada masa lampau yang digunakan untuk mempermudah mengangkut kayu jati dari daerah Kedungjati menjadi keuntungan karena dengan adanya aktivitas tersebut dibangunlah jalur kereta api di daerah Kedungjati dan menghubungkan ke beberapa kota di Jawa Tengah.

\subsection{Konsep}

Konsep dasar dari desain lanskap Stasiun Kedungjati adalah konsep Indis dengan menyesuaikan dengan arsitektur Indis pada Stasiun Kedungjati. Gaya Indis merupakan perpaduan antara budaya barat dan Indonesia khususnya Jawa/Arsitektur Indis biasanya disertai dengan kebun-kebun yang luas. Kebun-kebun tersebut disusun dengan jajaran tanaman yang tumbuh di dalam pot. Elemen yang biasanya ada yaitu air mancur, pagar-pagar hias, jembatan mini dan pohon-pohon yang dipangkas dengan bentuk geometris. Elemen lokal atau Indonesia dalam kebun tersebut adalah jenis tanaman lokal dari berbagai pulau serta tanaman obatobatan. Gaya arsitektur Indis tersebut akan diimplementasikan pada konsep desain lanskap

Konsep tata ruang merujuk pada UU No. 11 Tahun 2010 tentang Cagar Budaya yang membagi tata ruang menjadi empat zona yaitu zona inti, zona penyangga, dan zona pengembang dan zona penunjang. Zona inti merupakan area perlindungan utama untuk menjaga bagian cagar budaya, zona inti pada tapak yaitu bangunan stasiun yang terdaftar sebagai cagar budaya. Zona penyangga merupakan area yang menyangga dan melindungi zona inti, zona penyangga pada tapak adalah taman, ruang terbuka hijau yang mengelilingi zona inti serta bangunan gudang dan rumah dinas yang merupakan bagian dari sejarah Stasiun Kedungjati. Zona pengembang merupakan area yang diperuntukkan bagi pengembangan potensi cagar budaya. Zona pengembang pada tapak adalah mushola, kantin, ruang laktasi dan merokok. Zona penunjang merupakan area yang diperuntukkan bagi penempatan sarana dan prasarana, zona penunjang tapak adalah terminal dan pangkalan ojek pada bagian terluar tapak. Konsep tata ruang dapat dilihat di Gambar 3.

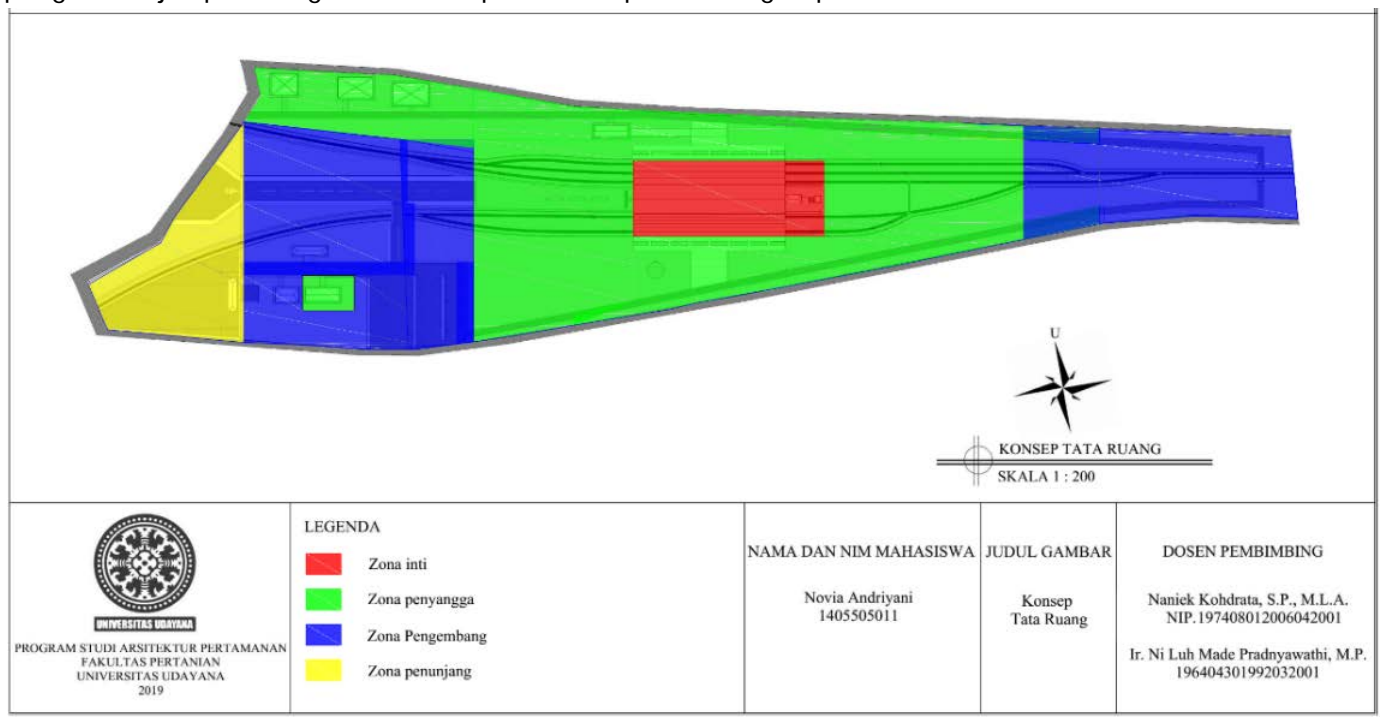

Gambar 3. Konsep Tata Ruang

Konsep tata hijau sangat berperan penting dalam desain tapak, jenis tanaman yang ditanam akan mempengaruhi kondisi dalam tapak. Konsep tata hijau berdasarkan konsep Indis yaitu dengan menggunakan tanaman lokal dan mengatur peletakan tanaman. Konsep tata hijau dibagi menjadi dua yaitu konsep tata hijau penyangga dan konsep tata hijau estetik. Tata hijau penyangga diletakkan di sekitar tapak atau pada batas tapak. Tata hijau penyangga berfungsi untuk menghalangi gangguan dari luar masuk ke dalam tapak, seperti gangguan kebisingan dan panas matahari dari luar tapak. Tata hijau estetik yaitu tanaman yang ditanam untuk memperindah tapak dan menjadi daya tarik bagi masyarakat dan pengunjung. 


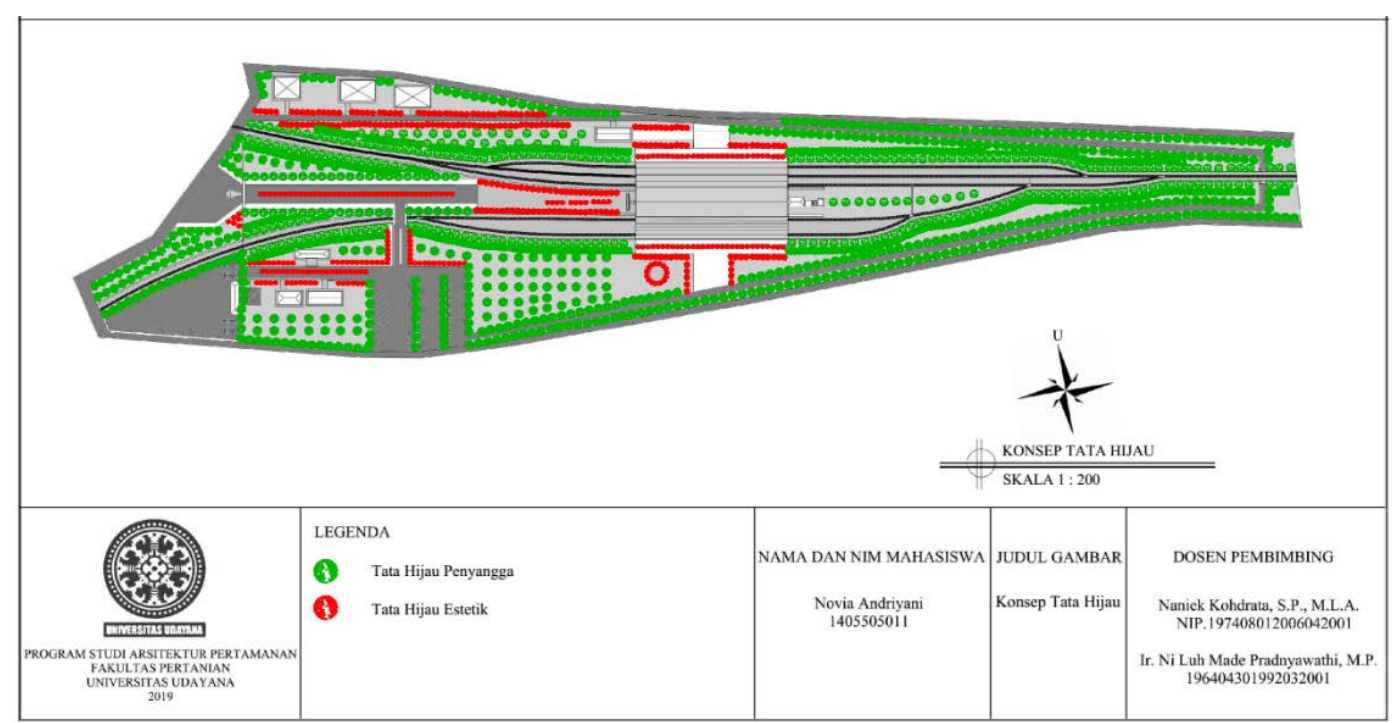

Gambar 4. Konsep Tata Hijau

Sirkulasi yang digunakan adalah pola sirkulasi terkontrol, supaya sirkulasi pengunjung lebih teratur. Sistem sirkulasi dibagi menjadi dua yaitu sirkulasi kendaraan dan sirkulasi manusia.

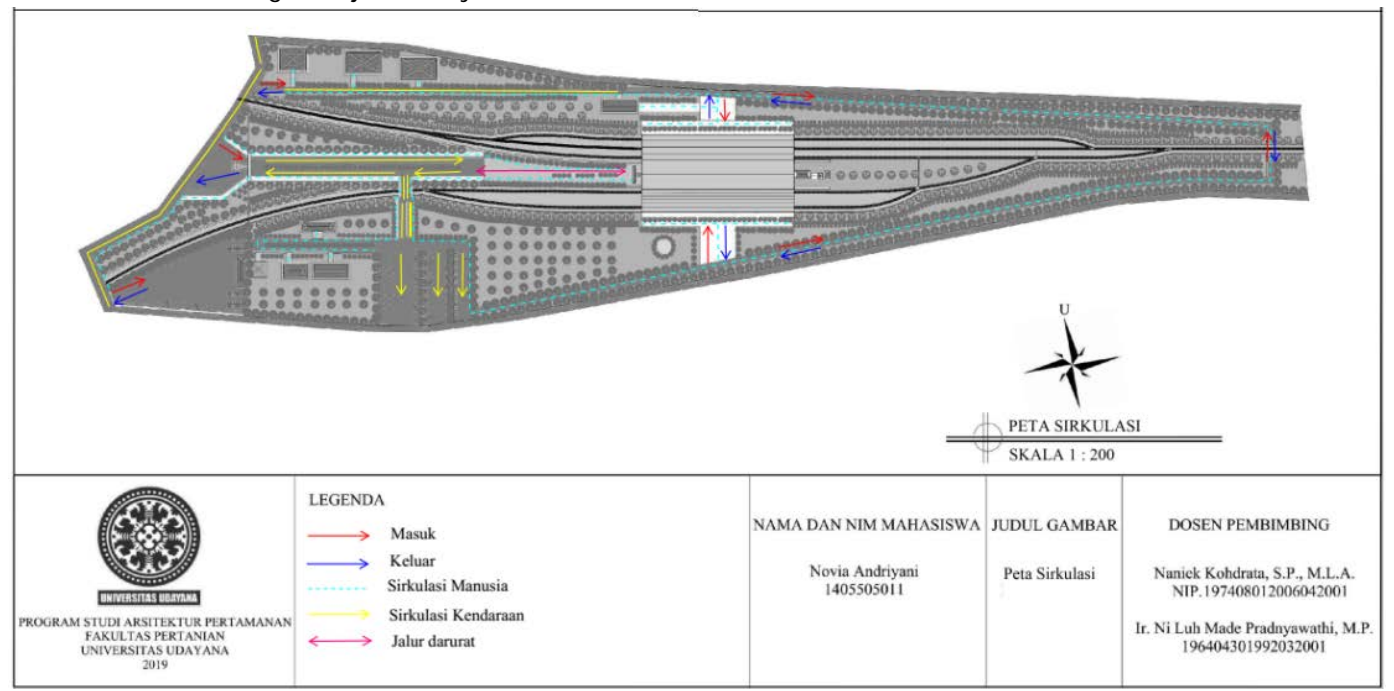

Gambar 5. Peta Sirkulasi

Konsep tata ruang, tata hijau dan sirkulasi yang telah dijabarkan selanjutnya akan digabung dan digambarkan dalam konsep desain lanskap. Penambahan bangunan pendukung disesuaikan dengan arsitektur stasiun yang bergaya Indis. Gaya belanda diterapkan pada bangunan pendukung dan juga elemen perkerasan pada taman. Gaya lokal Jawa diterapkan pada pemilihan jenis tanaman dengan tanaman lokal Indonesia. Ciri khas arsitektur Indis adalah peletakan bangunan berada di tengah dan memiliki kebun atau taman yang luas diterapkan pada desain tapak. Mengatur dan menyediakan sirkulasi manusia dan kendaraan pada tapak untuk menunjang dan mempermudah pengunjung pada tapak dalam memasuki dan menggunakan transportasi kereta api pada tapak.

Pembuatan taman dan ruang terbuka hijau yang luas mengelilingi tapak bertujuan untuk menunjang kelestarian bangunan. Penambahan elemen air mancur pada bagian selatan stasiun merupakan salah satu ciri arsitektur Indis dan juga keindahan tapak. Bangunan pendukung seperti rumah dinas, gudang, kantin dan mushola pada tapak bertujuan untuk melindungi bangunan stasiun pada zona inti. Terminal dan pangkalan ojek tersedia pada bagian terluar tapak sebagai penunjang pengembangan tapak supaya pengunjung lebih mudah mengunjungi tapak. 


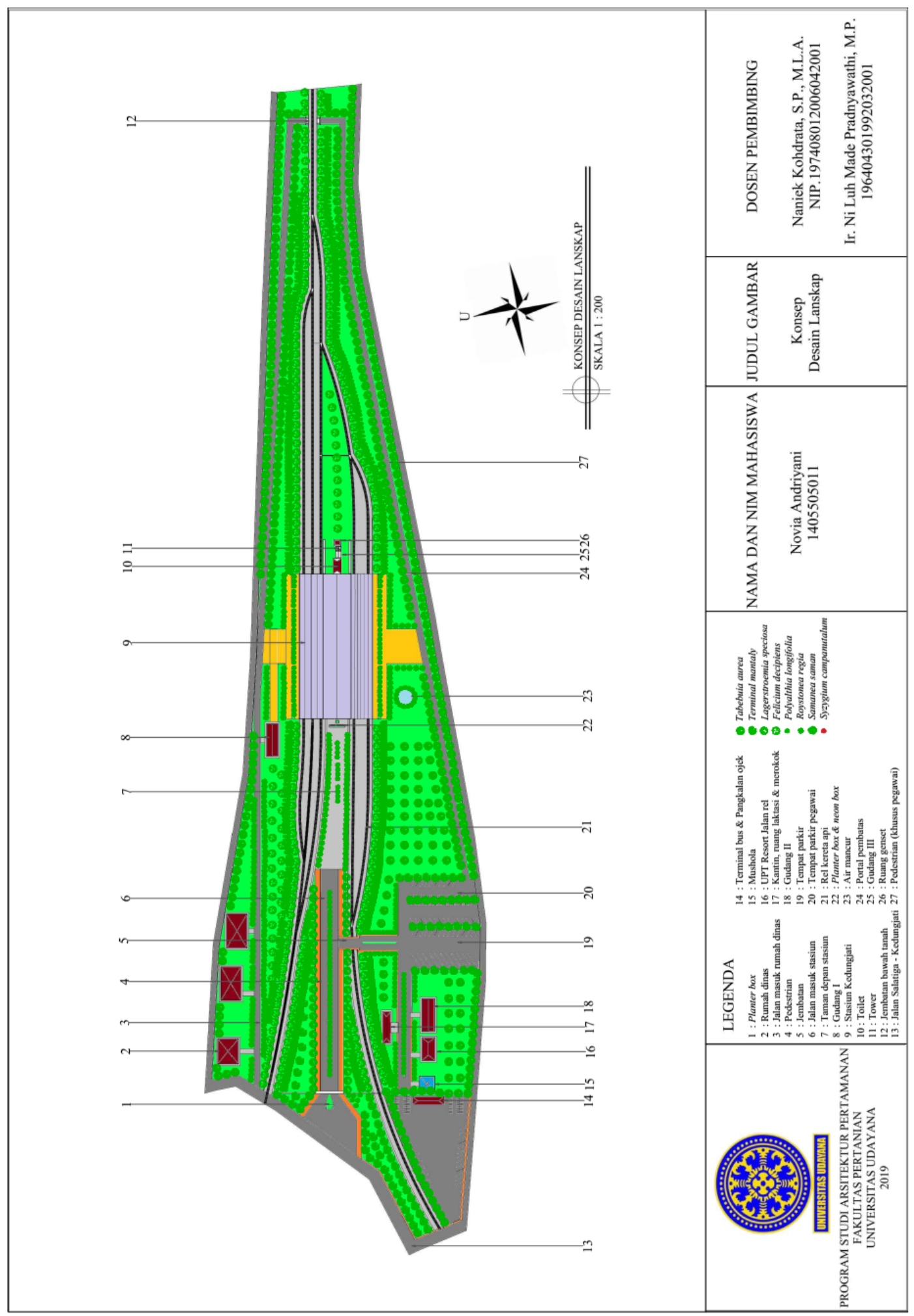

Gambar 5. Konsep Desain Lanskap 


\section{Simpulan}

Stasiun Kedungjati yang terletak di Kabupaten Grobogan Jawa Tengah, merupakan stasiun kereta api yang berusia 151 tahun dan terdaftar sebagai bangunan cagar budaya. Saat ini dikelola oleh PT. KAI DAOP IV Semarang bagian Heritage. Memiliki keindahan bangunan yang bergaya Belanda.

Stasiun Kedungjati mengalami perluasan fungsi seperti digunakan untuk menyelenggarakan acara hiburan, berolahraga, dan tempat berkumpul dan bersosialisasi. Pengaturan zonasi pada Stasiun Kedungjati merujuk UU No. 10 Tahun 2011 Tentang Cagar Budaya perlu diterapkan untuk mendukung pelestarian tapak. Lanskap stasiun dizonasikanmenjadi empat area, yaitu zona inti, zona penyangga, zona pengembangan dan zona pendukung. Zona inti yaitu bangunan stasiun yang sudah terdaftar sebagai cagar budaya. Zona penyangga yaitu taman dan ruang terbuka hijau yang melindungi tapak. Zona pengembangan yaitu fasilitas dan bangunan pendukung tapak. Zona penunjang sebagai sarana dan prasarana yaitu terminal dan pangkalan ojek. Konsep desain lanskap yang mendukung pelestarian bangunan sebagai bangunan cagar budaya menggunakan tema lanskap Indis, sebagai upaya menyelaraskan dengan arsitektur bangunan stasiun kereta yang bergaya Indis.

\section{Daftar Pustaka}

Apiwie, V.W dan Utomo, B.C. 2015. Stasiun Kereta Api Kedungjati dan Perekonomian Desa Kedungjati Tahun 1966-1989. Universitas Negeri Semarang, ISSN 2252-6633.

Badan Pusat Statistik Kabupaten Grobogan.2018. Kecamatan Kedungjati dalam Angka 2018. Badan Pusat Statistik. Grobogan

Badan Pusat Statistik Provinsi Jawa Tengah. 2017. Suhu Udara Rata-Rata Menurut Stasiun di Jawa Tengah, 2010 - 2016 (OC). Available online at http://jateng.bps.go.id (diakses pada 9 Desember 2018).

Balai Pelestarian Cagar Budaya Jawa Tengah. 2013. Inventarisasi Benda Cagar Budaya Kabupaten Grobogan 2013. Balai Pelestarian Cagar Budaya. Klaten.

Gold, S.M. 1980. Recreation planning and design. The McGraw-hill Book Companies. New York.

Hakim, R dan H. Utomo. 2003. Komponen Perancanangan Arsitektur Lansekap : Prinsip, Unsur, dan Aplikasi Desain. PT. Bumi Aksara. Jakarta.

Kementrian Pendidikan dan Kebudayaan. 2019. Sistem Regitrasi Nasional Cagar Budaya-Stasiun Kedungjati. Available online at http://cagarbudaya.kemendikbud.go.id (diakses pada 5 Oktober 2019).

Laurine, M. 1986. Pengantar Kepada Arsitektur Pertamanan (Terjemahan). Intermatra. Bandung. Marzuki. 2002. Metodologi Riset. Prasetya Widi pratama. Yogyakarta.

Republik Indonesia. 2010. Undang-Undang Republik Indonesia Nomor 11 Tahun 2010 Tentang Cagar Budaya. Departemen Dalam Negeri. Jakarta. 